NBER WORKING PAPER SERIES

\title{
EQUILIBRIUM CONSEQUENCES OF CORRUPTION ON FIRMS: EVIDENCE FROM CHINA'S ANTI-CORRUPTION CAMPAIGN
}

\author{
Haoyuan Ding \\ Hanming Fang \\ Shu Lin \\ Kang Shi \\ Working Paper 26656 \\ http://www.nber.org/papers/w26656 \\ NATIONAL BUREAU OF ECONOMIC RESEARCH \\ 1050 Massachusetts Avenue \\ Cambridge, MA 02138 \\ January 2020
}

We are grateful to seminar participants at Tsinghua University, Shanghai University of Finance and Economics, and NBER Chinese Economy conference (2017) for comments and suggestions that significantly improved the paper. Ding acknowledges financial support from the National Natural Science Foundation of China (no. 71703086). Fang acknowledges the financial support from the China Research Engagement Fund of the University of Pennsylvania. We are responsible for all remaining errors. The views expressed herein are those of the authors and do not necessarily reflect the views of the National Bureau of Economic Research.

NBER working papers are circulated for discussion and comment purposes. They have not been peer-reviewed or been subject to the review by the NBER Board of Directors that accompanies official NBER publications.

(C) 2020 by Haoyuan Ding, Hanming Fang, Shu Lin, and Kang Shi. All rights reserved. Short sections of text, not to exceed two paragraphs, may be quoted without explicit permission provided that full credit, including $(\odot$ notice, is given to the source. 
Equilibrium Consequences of Corruption on Firms: Evidence from China's Anti-Corruption

Campaign

Haoyuan Ding, Hanming Fang, Shu Lin, and Kang Shi

NBER Working Paper No. 26656

January 2020

JEL No. D7,D72,G34,G38

\section{$\underline{\text { ABSTRACT }}$}

We use China's recent anti-corruption campaign as a natural experiment to examine the (market expected) equilibrium consequences of (anti-)corruption. We argue that the announcement of inspections of provincial governments by the Central Commission for Discipline Inspection (CCDI) on May 17, 2013 represents a significant departure of past norms of anti-corruption campaigns, and thus serves a rare empirical opportunity to examine the equilibrium effects of anti-corruption campaigns for firms. We first present a conceptual framework to illustrate the channels through which anti-corruption actions can influence firms. Using an event study approach and May 17, 2013 as the event date, we find that, overall, the stock market responded positively to the announcement of strong anti-corruption actions. The announcement returns are significantly lower for luxury-goods producers, and SOES, large firms, or politically connected firms earn lower returns than private, small, or non-connected firms. We also find that existing local institutions play a crucial role in determining the announcement returns across firms. Moreover, a long-term difference-in-differences analysis shows that higher returns during the event window are associated with more subsequent entries of new firms and faster expansions of existing firms. Finally, we also provide direct evidence consistent with the endogenous grits effect.

Haoyuan Ding

Shanghai University of Finance and Economics Shanghai, China

ding.haoyuan@mail.shufe.edu.cn

Hanming Fang

Department of Economics

Ronald O. Perelman Center

for Political Science and Economics

133 South 36th Street

Suite 150

Philadelphia, PA 19104

and NBER

hanming.fang@econ.upenn.edu
Shu Lin

Department of Economics Chinese

University of Hong Kong Shatin,

New Territories

Hong Kong

shulin75@gmail.com

Kang Shi

Department of Economics Chinese

University of Hong Kong Shatin,

New Territories

Hong Kong

kangshi@cuhk.edu.hk 


\section{Introduction}

Corruption is a widespread phenomenon in many developing and transitional economies. A crucial, yet unsettled, question is: what are the consequences of corruption? There are two different views of the effect of corruption on economic development. ${ }^{1}$ The conventional wisdom holds that corruption is a distortion and is costly for economic development (e.g., Klitgaard, 1991; La Porta, et al., 1999; Shleifer and Vishny, 1993). The "grabbing hands" of bureaucrats increase the cost of operating business, leading to less entry on the extensive margin and to smaller scale on the intensive margin. Under this view, eliminating governments' grabbing hands will lead to more firm entry and higher profits for existing firms and in general will improve economic efficiency.

An alternative view, however, argues that in an environment with excessive bureaucratic burden, paying bribes may help avoid bureaucratic delays and make government officials work harder. This view is first put forth by Leff (1964) in his influential essay "Economic Development Through Bureaucratic Corruption" where he laid out several arguments for the possible efficiency-enhancing role of corruption. As Leff put it: "The critique of bureaucratic corruption often seems to have in mind a picture in which the government and civil service of underdeveloped countries are working intelligently and actively to promote economic development, only to be thwarted by the efforts of grafters. Once the validity of this interpretation is disputed, the effects of corruption must also be reevaluated." Leff suggested that the government would often be indifferent or even hostile to entrepreneurs, and it could establish misguided anti-market policies in the form of crushing government bureaucracy and red tapes; bribery of government officials would help the market

\footnotetext{
${ }^{1}$ See Bardhan (1997) for a review of these issues and also see Chapter 4 of Fisman and Golden (2017) for the consequences of corruption.
} 
function by allowing the entrepreneurs who pay the bribes to avoid the shackles of the bureaucracy. ${ }^{2}$ This view of corruption as the "grease for the squeaking wheels" of a rigid administration is famously summarized by Huntington (1968, p. 386): "In terms of economic growth, the only thing worse than a society with a rigid, over-centralized, dishonest bureaucracy is one with a rigid, over-centralized, honest bureaucracy."

These two views are not necessarily conflicting. To the extent that red tapes and misguided regulations are endogenous choices of bureaucrats, rent-seeking incentives by the bureaucrats can serve as the source of the red tapes and misguided regulations that lead to distortions; and at the same time, corruption can serve as the grease to at least partially undo the distortions by the red tapes and misguided regulations. The effect of corruption on economic performance in this equilibrium framework is more nuanced. In the absence of the opportunities to engage in rent-seeking, the red-tapes and misguided regulations may not be present, thus making moot the "grease-of-the-wheel" role of corruption. However, whether the opportunities of corruption by the bureaucrats increase or hinder the economy crucially depends on the institutions (including government regulations) that would be in place when corruption is rooted out (see, e.g., Kaufmann and Wei, 1999, and Wei, 2000a, 2000b).

In order to evaluate the equilibrium consequences of corruption on firms, one would need to observe firms' performance under different norms of corruption, ceteris paribus. This poses an empirical challenge, however. In most of the cases, the norms of corruption in a country change only in conjunction with a radical change in the

\footnotetext{
${ }^{2}$ Leff also suggested the corruption may help economic development by "making possible a higher rate of investment than would otherwise be the case", because corruption can enable entrepreneurs to "control and render predictable this important influence [of harmful government intervention on their affairs] on their environment." In addition, he argued that corruption can increase development since the market for bribery itself may lead to scare resources such as licenses to be allocated more efficiently.

${ }^{3}$ See also, e.g. Beck and Maher (1986), Lien, (1986) and Méon and Sekkat (2005) among others.
} 
government caused by either uprising, revolution, or foreign invasion. Therefore, it is impossible to disentangle the effect of corruption on firms from other disturbances to the economy. A substantial shift in the norms of corruption among bureaucrats in a stable country and economy usually do not happen simultaneously. In this paper, we argue that China's recent strong anti-corruption campaign under President Xi Jinping, in particular, the announcement that the Central Commission for Discipline Inspection (CCDI) would conduct several rounds of inspection on May 17, 2013, may signal as the event suggesting Xi's anti-corruption campaign was not business-as-usual, thus serving as a rare natural experiment that can allow us to examine the equilibrium consequences of corruption on firms. ${ }^{4}$ The CCDI inspections were sweeping, and resulted in the detainment and prosecution of more than 270,000 bureaucrats at different levels, including more than 100 high-ranking government officials. This unprecedented announcement of the inspections by CCDI is likely to have resulted in a shift in public perception about the nature of President Xi's anti-corruption campaign, and possibly a shift in the norm of corruption among bureaucrats.

A second empirical challenge is that it would likely take a long time for the equilibrium outcomes following the shift of the corruption norm to fully manifest itself; but during the long time horizon many other factors can also change, which would then make it harder to distinguish the effect of the changes in the corruption norm from the effects of other concurrent changes. To overcome this empirical challenge, we take advantage of the fact that stock market incorporates expectations about the future developments in the current pricing of a firm's equity; thus, to the extent that the market expects the anti-corruption campaign to lead to both short- and

\footnotetext{
${ }^{4}$ In Section 2 we provide more background information about Xi's anti-corruption campaign and argue why the announcement of inspection of provincial governments by CCDI on May 17, 2013 was different from past practices.
} 
long-run (i.e., equilibrium) changes in the extent of corruption in the economy, the equilibrium effects of corruption on firm values will be reflected in the changes in the stock market prices upon the announcement of the CCDI inspections.

Specifically, we employ an event study approach and use the announcement date, May 17, 2013, as our event date, to examine the cumulative abnormal returns (CAR) of publicly listed stocks around the announcement date. We find that the stock market overall responded significantly positively to the CCDI inspection announcement, indicating that the market views this new phase of anti-corruption campaign a positive news that will improve firms' overall performance once a new corruption norm is reached. This finding is despite the fact that there have been previous anti-corruption measures since $\mathrm{Xi}$ assumed power, thus it serves as strong evidence that the CCDI inspection announcement was considered to be a significant event by the market: it indicates that Xi's anti-corruption campaign is not merely business as usual.

We then conduct regression analyses to examine the potential determinants of the CARs, which will then inform us about the possible mechanisms through which corruption (or anti-corruption) can impact firm performance. The regression results reveal a substantial amount of heterogeneity across firms. First, there is strong evidence supporting a market demand channel. The CARs are found to be significantly lower for firms that produce luxury goods, which are often used as gifts to bribe government officials (e.g., Cai, Fang, and Xu, 2011; Qian and Wen, 2015). Second, we find that the announcement returns are significantly higher for private firms, small firms, or firms with no established political connections. On the one hand, these firms suffer more from governments' grabbing hands. On the other hand, they also rely more on the efficiency grease in a corrupt environment. Our finding is thus consistent with the general equilibrium view. That is, for sufficiently strong 
anti-corruption measures, the benefits from eliminating governments' grabbing hands can dominate the costs associated with the loss of the efficient grease. In addition, there is also evidence that local institutions matter. While private, small or firms without political connections earn higher announcement returns than state-owned, large, or connected firms, the return differentials are significantly lower in provinces with better legal protections (a smaller grabbing-hand effect) or less developed factor markets (a larger grease-of-wheel effect).

Next, we further examine the long-term impacts on firm entry and the scales of existing firms using a generalized difference-in-differences approach. Specifically, we interact the industry average CARs calculated during the event window with a post-event dummy and estimate the effects of this interaction term on the entry of new firms in an industry-year panel (and a province-industry-year panel as well). We also estimate the long-term effect of this interaction term on the scales of existing firms in a panel of listed firms. If all new relevant information is fully reflected in firms' stock prices so that the computed CARs during the event window capture the expected net impact of all avenues of exposure to the anti-corruption campaign, we should expect more firms to enter industries with higher average CARs after the campaign on the extensive margin. Similarly, on the intensive margin, we should expect firms with higher CARs to expand more in their scales.

The estimated long-term effects from the generalized DID approach are consistent with our hypothesis. Using the Chinese Firm Registration data that covers the universe of China firms, we find that at both the industry-level and the more disaggregate province-industry level, higher average CARs during the event are associated with significantly more subsequent entries of new firms. In the listed firm sample, we also find that, on the intensive margin, firms with higher CARs expand 
significantly after the anti-corruption campaign.

Finally, we also provide direct evidence on the "endogenous grits effect" (see Section 3) that is crucial to our equilibrium analysis of the economic consequences of anti-corruption actions. Using both the World Bank's "Ease of Doing Business Index" and the marketization index, we find strong evidence consistent with the prediction that there was significant improvement of China's institutional environment for business after the anti-corruption campaign.

Our work contributes to the corruption literature by offering evidence about the likely equilibrium impact of corruption on firm performance based on a large-scale persistent anti-corruption campaign by President Xi. Most of the previous empirical studies in this literature take a macro approach by relating corruption measures to economic growth or other macro variables, such as capital flows (e.g. Mauro, 1995; Mo 2001; Wei, 2000b, 2001; Javorcik and Wei, 2009). Some more recent studies have also examined the private returns of bribing government officials at the firm level (Fisman and Svensson 2007; Cai, Fang, and Xu, 2011). This paper contributes to the existing literature by providing micro evidence on the effects of anti-corruption actions. We also make efforts to distinguish different channels and explore potential heterogeneity across firms.

Our study also fits in a narrower literature on corruptions that focuses particularly on the case of China. A majority of the existing studies focus on detecting corruption behavior in China. For example, Fisman and Wang (2014) identify corruption behavior in the sales of state assets in China. Fang, Gu, and Zhou (2014) find that government officials receive discounts in real estate purchases. Fisman and Wei $(2004,2009)$ use trade data to detect corruption behavior of Chinese customs. Cai, Fang, and $\mathrm{Xu}$ (2011) find Chinese firms often use entertainment and travel 
expenditures to bribe government officials. They also analyze firms' private return of paying bribes.

In particular, our paper is related to several recent working papers that also examine the impacts of various aspects of Xi's anti-corruption campaign. Qian and Wen (2015) examine the effect of the recent anti-corruption on imports of luxury goods. They find a substantial reduction in imports of luxury goods upon the initiation of Xi's anti-corruption campaign. Li, Wang, and Zhou (2017) empirically examine the impact of $\mathrm{Xi}$ 's anti-corruption campaign on the credit allocation between the state-owned enterprises (SOEs) and the privately-owned non-SOE firms, and they show that the anti-corruption campaign leads to a credit reallocation from inefficient SOE firms to more productive private firms. Berkowitz, Lin and Liu (2015) study the impact of File 18 regulation issued on October 30, 2013 which required "politically connected" independent directors to resign from the boards. They show that the stock market returns for the private firms with politically connected independent directors suffered relative to those of non-connected private firms upon the issuance of File 18 regulation. They also find evidence that the File 18 regulation encouraged private firms that had politically connected independent directors to become more innovative and more transparent and more efficient investors. Finally, perhaps the most related paper to ours is Lin, Morck, Yeung, and Zhao (2016), which also used event study to investigate the impact of the Eight Point Regulation issued on December 4, 2012 on stock market valuations. They find that Chinese shares rose broadly upon the news of the Eight Point Regulation, suggesting that reduced expected corruption adds value to the firms overall. They also find that the impact is heterogenous: SOEs gain broadly, but non-SOEs gain in more liberalized provinces, but decline in provinces where market institutions remain weak. 
Our paper is closely related to the above studies, but there are several key differences that distinguish ours from existing contributions. First, while existing studies focus on some specific effects of anti-corruption actions, such as luxury imports or the differential effects on SOEs and non-SOEs, we aim to provide a more comprehensive analysis on the effects of the anti-corruption campaign on firms and to identify different channels. Second, to rationalize our empirical study, we also provide a simple theoretical framework to illustrate the underlying mechanisms through which anti-corruption actions can influence firms. Moreover, while all studies examine the impacts of the broadly-defined recent anti-corruption campaign in China, the exact event each study analyzes is in fact rather different. Qian and Wen (2015) focus on two events, the release of a new manifesto by the Third Plenum of the 18th CCP on November 15th, 2013 and the release of CCP's a five-year anti-graft plan on December $25^{\text {th }}, 2013$. Lin, Morck, Yeung, and Zhao (2016) examine the impacts of the Eight-point Regulation policy on government officials' spending of public revenues announced on December 4, 2012. Li, Wang, and Zhou (2017) study the investigation of the CEO of Minsheng Bank, one of the largest commercial banks in China. In contrast, we analyze the stock market responses to the announcement of anti-corruption inspections to be conducted by the CCDI on May 17, 2013, which is considered to be a symbolic event of China's anti- corruption campaign. As we shall discuss in more details in Section 2, this announcement is not only a surprise to the market but also sends a clear message to market participants about a strong commitment to fighting corruptions. The anti-corruption inspections would result in serious investigations and arrests of corrupt government officials. Thus, the CCDI announcement was likely a significant new phase of the anti-corruption campaign that could result in an equilibrium response of bureaucrats' behavior. Finally, in addition 
to exploring stock market responses, our study also utilizes a generalized difference-in-differences approach to exam the long-term effects of the anti-corruption campaign on entry of new firms and the scales of existing firms.

The remainder of this paper is structured as follows. In Section 2 we present the institutional background for the anti-corruption campaign. In Section 3, we present a simple conceptual framework that incorporates various channels of the effect of corruption and use it to derive our testable hypotheses. In Section 4 we describe the data set we use in the empirical analysis. In Section 5 we report our empirical results. Finally, in Section 6 we conclude.

\section{Institutional Background}

Like many developing countries, corruption is a central issue in China. Xi Jinping officially assumed the title of the General Secretary of Communist Party and Chairman of the Party Central Military Commission on November 14, 2012 at the conclusion of the Party's 18th National Congress. The new leadership in China considers corruption as not merely a significant problem to economic growth but a real threat to the party's survival. Almost immediately upon assuming power, $\mathrm{Xi}$ started an anti-corruption campaign. On November 20, 2012, the Central Commission for Discipline Inspection (CCDI), which was led by Xi's close ally and CPC Politburo Standing Committee member Wang Qishan, issued a warning that "the public's trust in the Party and the government has fallen to a critical level" and argued that the Party must fight corruption and treat anti-corruption as a major political task. ${ }^{5}$ On December 4, 2012, CPC Politburo of the Central Committee issued a policy document titled the Eight-Point Regulation, which provides explicit rules regarding the behavior

\footnotetext{
5 Xinhua News, November 20, 2012.
} 
of leading cadres from the Communist party, and bans bureaucrats and employees of state-owned firms of extravagant house, luxury goods purchases, and state-funded banquets. However, in China anti-corruption campaigns were often waged after an important political transition, and often such campaigns were short-lived and considered possible tactics to weaken or purge political opponents in order to consolidate power. Moreover, no concrete measures were mentioned in the Eight Point regulations regarding how the regulations would be enforced. Since similar anti-corruption announcements were also made by previous leaders, the market did not view them as a credible commitment to fighting corruption (Qian and Wen, 2015). The expectation at the time when the Eight-Point Regulation was issued was that this was yet another anti-corruption campaign by President Xi that would be short-lived.

Concrete and more credible investigation and punishment actions arrive in the middle of 2013. On May 17, 2013, the Central Commission for Discipline Inspection (CCDI), which is the highest internal-control institution within the party system, made an announcement that it will conduct several rounds of inspections. In the first round of inspections, the CCDI will send inspection teams to five provinces, including Chongqing, Guizhou, Jiangxi, Inner-Mongolia, and Hubei.

Inspection teams are responsible to examine every ministry and government agencies for each province. As leaded by CCDI's secretary, Wang Qishan, the inspection teams have the unlimited power to investigate, detain, and interrogate almost anyone that may be involved in bribery, embezzlement, trading power for profit and other personal favors, no matter how high ranking they are. The inspection teams first will perform a background checks of the provinces or organizations to be inspected. Then the teams will stay in the inspected provinces for two months or so and the teams' contact information is released to the public. During the two-month 
inspection, the inspectors collect information with the help of local discipline inspectors and anti-graft agency officers, and take tips from the public and retired government officials. If there is evidence of corruption, the inspectors will make records and report it to the CCDI.

Compared to previous anti-corruption measures, the CCDI inspection has a concrete plan and emphasizes on fighting corruption at all levels of governments. This announcement is an unexpected shock and a wake-up call for both government officials and the market participants. It is quite clear to them that this time is different. The inspections are often interpreted as the symbolic event of the start of China's recent anti-corruption campaign. While the announcement on May 17, 2013 did not mention explicit which provinces will be inspected later, it is quite clear that each province will eventually be inspected. As a result, we expect its impact is not regional but national. Firms located in other provinces will also be affected. Indeed, in our empirical analysis, we do find that its impact is national.

During the period of 2013-2014, the CCDI conducted a total of four rounds of inspections, covering all provinces in China (see Appendix A). The inspections broke the unspoken rule regarding "Politburo Standing Committee criminal immunity" by arresting the former Politburo Standing Committee Member Zhou Yongkang (expelled from the Party and sentenced to life in prison). Over 100 high-ranking government officials, and more than 270,000 bureaucrats at different levels were detained and punished for corruption activities. Our study examines how the stock market responds to the announcement of this large-scale anti-corruption campaign.

\subsection{Why is the Announcement of CCDI Inspection Different?}

Anti-corruption has been an official theme since President Xi Jinping officially became the Party Secretary in the Eighteenth National Congress. The first official 
pronouncement of the anti-campaign is the Eight-Point Regulation announcement on December 4th, 2012, just weeks after the end of the Eighteenth National Congress. In Appendix $\mathrm{C}$ we provide the details of the Eight-Point Regulation. It mainly regulates the behavior of the political bureau members going forward. We argue that while Eight-Point Regulation is a significant event, it was unlikely to be the event that would suggest this anti-corruption campaign to be "different." First, the issuance of Eight-Point Regulation was very shortly after the 18th National Congress, and this was a routine action taken by a new leadership. So to the officialdom, this may still suggest that the campaign might be temporary. Second, the Eight-Point Regulation did not specify punishments and enforcement. Third, an ex post examination of the officials above the vice-ministerial level since 2012 showed that only two officials at the vice-ministerial level were investigated after the Eight-point Regulation but before the CCDI inspection announcement. The majority (over 160) were investigated after the inspection announcement, including 21 top officials at the ministerial level or above. Moreover, among all investigated officials, only 12 were due to the violation of the Eight-point Regulation, and these 12 officials all got minimal punishment such as official warning. Finally, it is worth pointing out that even though 2 vice-ministerial level officials were investigated between the Eight-Point Regulation announcement and the CCDI inspection announcement, we also observe that, the pace was not unusual relative to the period before the Eight-Point Regulation announcement. From 2008 to 2012 before the Eight-Point Regulation announcement on December 4, 2012, a total of 38 officials at the vice-ministerial level were investigated. Thus, the investigation of two officials at the vice-ministerial level after the Eight Point Regulation was indeed nothing more than business-as-usual from an ex post perspective. 


\section{Conceptual Framework and Testable Hypothesis}

\subsection{A Simple Conceptual Framework}

In this section, we provide a simple conceptual framework to motivate our empirical analyses. We consider a game between bureaucrats and firms, and study how a strong anti-corruption campaign may change firm performance. Base on the simple framework, we shall develop several testable hypotheses. Let $b$ denote the corruption activity by government officials. We hypothesize that corruption activity by government officials can affect firm $i^{\prime} s$ net profit via four channels:

1. Grabbing Hand Channel. We model this by assuming that the "effective tax rate" of a firm, $t$; is a non-decreasing function of $b$ : We denote $t\left(b ; X_{i}\right)$ as tax rate of firm $i$; with characteristics $X_{i}$, when corruption activity is $b$; with $t^{\prime}\left(\cdot ; X_{i}\right) \geq 0$. It should be understood that the effectiveness tax rate is inclusive of both the tax the firm pays to the tax authority and the bribe $b$ extracted by the bureaucrats. The tax the firm pays to the tax authority may be a decreasing function of $b$.

2. Grease of Wheel Channel. We model this by assuming that the marginal cost of production for firm $i$, denoted by $C\left(b ; X_{i}\right)$, is a non-increasing function of $b$, i.e., $C^{\prime}\left(\cdot ; X_{i}\right) \leq 0$

3. Endogenous Grits Channel. Alternatively, this could be referred to as the equilibrium channel. We assume that the grits of the bureaucracy that affects the firm's marginal cost of production are partly chosen by the bureaucrats. For simplicity, we assume that the bureaucrats can choose between two marginal cost functions $C_{H}\left(b ; X_{i}\right)$ and $C_{L}\left(b ; X_{i}\right)$, and the two marginal cost functions are related as follows:

$$
C_{H}\left(b ; X_{i}\right)=\kappa C_{L}\left(b ; X_{i}\right)
$$


where $\kappa \in(0,1)$. Thus, one can interpret bureaucrat's choice of $H$ as heavy regulation and more license requirements, while the choice of $L$ is light regulation and less licensing requirements.

4. Market Demand Channel. Corruption activity may also affect a firm's profit by affecting its demand. For example, many high-end consumer products are popular choices for bribing government officials. We model this by assuming that the demand curve faced by firm $i, Q\left(p, b ; X_{i}\right)$, depends on $b$. That is, we assume that $Q_{2}\left(p, ; X_{i}\right) \equiv \partial Q / \partial b$ is not necessarily zero. The exact sign of $Q_{2}$ may depend on firm $i^{\prime} s$ main product. If firm $i$ produces higher- end consumer products, it is natural to hypothesize that $Q_{2}>0$; but if $i$ produces lower-end consumer products, $Q_{2}<0$ due to substitution.

We suppose that the bureaucrats choose the regulatory regime $r \in\{H, L\}$. They understand that there is an expected penalty if they are caught accepting bribes. The penalty function is given by

$$
D(B ; a)
$$

where $B$ is the bribe taken by the bureaucrat and $a$ represents the anti-corruption intensity. Naturally, we assume that $\partial D / \partial B>0$ and $\partial D / \partial a>0$, and $D_{12}>0$.

The bureaucrats' objective function is a weighted average of the bribes net of the expected penalty and the net tax revenues received by the government. Specifically, we assume that the bureaucrats' payoff function is given by

$$
u(B ; T)=\lambda B+(1-\lambda) T-D(B ; a)
$$

where $B$ is the total bribe collected from the firms, $T$ is the total net tax revenue, and $\lambda \in(0,1)$ is the weight on the bribe in the bureaucrats' payoff function.

In the economy, firms have heterogeneous characteristics denoted by $X_{i}$. In the population of firms, $X_{i}$ is assumed to have a distribution $F(\cdot)$. For each firm with 
characteristics $X_{i}$, the net profit function, when it pays bribe $b$ and charges price $p$ is given by:

$$
\pi\left(p, b ; X_{i}\right)=\left[1-t\left(b ; X_{i}\right)\right]\left[p-C_{r}\left(b ; X_{i}\right)\right] Q\left(p, b ; X_{i}\right)
$$

In the analysis below, we assume that bureaucrats choose regulatory regime $r \in$ $(H, L)$ and also dictate a bribe level $b_{i}$ from each firm $i$, and the firm chooses only the price $p_{i} \cdot{ }^{6}$

Let us first consider the first case. A firm with characteristics $X_{i}$ will choose $p_{i}$ to maximize

$$
\prod\left(X_{i} ; r\right) \equiv \max _{\left\{p_{i}\right\}}\left[1-t\left(b_{i} ; X_{i}\right)\right]\left[p_{i}-C_{r}\left(b_{i} ; X_{i}\right)\right] Q\left(p_{i}, b_{i} ; X_{i}\right)
$$

Let the optimal price for firm $i$ be denoted by $p_{i}^{*}\left(X_{i} ; b_{i}, r\right)$.

By the Envelope Theorem, we have

$$
\begin{gathered}
\left.\frac{\partial \prod\left(X_{i} ; r\right)}{\partial b_{i}}\right|_{r}=\overbrace{-t^{\prime}\left(b_{i} ; X_{i}\right)\left[p_{i}^{*}\left(X_{i} ; b_{i}, r\right)-C_{r}\left(b_{i} ; X_{i}\right)\right] Q\left(p_{i}^{*}(b, r), b_{i} ; X_{i}\right)}^{\text {Grabbing Hand Effect }} \\
\qquad \overbrace{-\left[1-t\left(b_{i} ; X_{i}\right)\right] C^{\prime}{ }_{r}\left(b_{i} ; X_{i}\right) Q\left(p_{i}^{*}\left(X_{i} ; b_{i}, r\right), b_{i} ; X_{i}\right)}^{\text {Grease of the Wheel Effect }} \\
\overbrace{+\left[1-t\left(b_{i} ; X_{i}\right)\right]\left[p_{i}^{*}\left(X_{i} ; b_{i}, r\right)-C_{r}\left(b_{i} ; X_{i}\right)\right] Q_{2}\left(p_{i}^{*}(b, r), B ; X_{i}\right)}^{\text {Demand Effect }}
\end{gathered}
$$

The first term captures the grabbing hand effect. As we will show below, the anti-corruption campaign reduces the demand for bribes from the bureaucrats even if the bureaucrats do not change the regulatory regime in response to the anti-corruption campaign, then since $-t^{\prime}\left(p^{*}-C\right) Q<0$, the grabbing hand effect will increase firm's profit. The second term captures the grease of wheel effect. When $b_{i}$ is

\footnotetext{
${ }^{6}$ Alternatively, we can assume that the bureaucrats choose only the regulatory regime $r \in(H, L)$ and each firm chooses $b_{i}$ and $p_{i}$ given the regulatory regime chosen by the bureaucrats. In such a case, the only way anti-corruption campaigns will affect the level of bribes and firm performance is that the bureaucrats choose a different regulatory regime. For simplicity, we have assumed only two regulatory regimes, $H$ and $L$; but we assume that there is a continuum of regulatory regimes indexed by $k$, then similar qualitative conclusions can be obtained in this alternative model as well.
} 
lowered in response to the anti-corruption campaign, and since $-(1-t) C_{r}^{\prime} Q>0$, the grease-of-wheel effect will lower the firm profit, conditional on the same regulatory regime. The third term $(1-t)\left(p_{i}^{*}-C\right) Q_{2}$ captures the demand effect. As anti-corruption campaign reduced the total demand for bribes $B$; then the demand curve for some firms, e.g., firms that produce luxury products or expensive meals that are often used as bribes, will be lowered. Whether this effect is positive or negative for a firm depends on the firm's characteristics $X_{i}$, which will affect the sign of $Q_{2}$.

What is not yet captured in (2) is the endogenous grits effect. To capture this, we need to describe the bureaucrats' choice of $b_{i}$ and $r \in\{H, L\}$. Fix $r \in\{H, L\}$. If the bureaucrats choose $b\left(X_{i}\right)$ for firms with characteristics $X_{i}$, the total bribes will be

$$
B^{r}=\int b\left(X_{i}\right) d F\left(X_{i}\right)
$$

and the total net tax revenue collected will be

$$
T^{r}=\int\left\{\begin{array}{c}
t\left(b\left(X_{i}\right) ; X_{i}\right)\left[p_{i}^{*}\left(X_{i} ; b_{i}, r\right)-C_{r}\left(b\left(X_{i}\right) ; X_{i}\right)\right] Q\left(p_{i}^{*}\left(X_{i} ; b_{i}, r\right), b_{i} ; X_{i}\right)- \\
b\left(X_{i}\right)
\end{array}\right\} d F\left(X_{i}\right)(4)
$$

For a given $r$, and facing anti-corruption intensity $a$, the bureaucrats' choice of bribes for firm with characteristics $X_{i}, b\left(X_{i}\right)$, solves:

$$
V^{r}(a) \equiv \max _{\left\{b\left(X_{i}\right)\right\}}\left[\lambda B^{r}+(1-\lambda) T^{r}-D\left(B^{r} ; a\right)\right]
$$

where $B^{r}$ and $T^{r}$ are given by (3) and (4) respectively. Clearly, for a given $r$, we have

$$
\left.\frac{\partial b^{*}\left(X_{i}\right)}{\partial a}\right|_{r}<0
$$

The bureaucrats' optimal choice $r^{*} \in\{H, L\}$ solves:

$$
r^{*}(a)=\underset{r \in\{H, L\}}{\operatorname{argmax}}\left\{V^{H}(a), V^{L}(a)\right\}
$$

The endogenous grits effect is captured by how $r^{*}(a)$ is related to the anti-corruption intensity $a$. When the anti-corruption intensity increases from $a_{0}$ to 
$a_{1}>a_{0}$, it is possible that the bureaucrats will switch from the high regulatory regime to low regulatory regime if taking bribes is too costly and the bureaucrats choose instead to focus on tax revenues. This is likely to happen when $\lambda$ is not very high. The switch to low regulatory regime will provide an additional boost to the firm's profits. However, when $\lambda$ is sufficiently high, it is also possible that the bureaucrats will stay within the high regulatory regime and demand less bribes, resulting in higher marginal costs for the firms.

To summarize, the effect of increasing the anti-corruption intensity $a$ will have four possible effects. Total bribes will decrease, but the net effect of anti-corruption on firm i's after-tax profit is ambiguous and depends on firm characteristics.

\subsection{Testable Hypotheses}

The above simple conceptual framework suggests that anti-corruption actions influence firms through different channels, and their effects are likely to be heterogeneous across firms. Below we derive some testable hypotheses based on the predictions of the simple model.

Hypothesis 1. The overall market response to the announcement is ambiguous. However, if market participants expect that the anti-corruption actions are strong enough to change the institutional constraints that give rise to the efficient grease effect of corruption in the first place, then the overall market reactions are likely to be positive.

Our simple model predicts that the anti-corruption actions affect firms through three channels. Since the market demand effect influences mainly a small fraction of firms that produce luxury goods, the overall announcement effect depends largely on the relative strength of the grabbing-hand effect and the grease-of-wheel effect. In a general equilibrium framework, however, the magnitude of the grease-of-wheel effect 
depends on market participants' expectations on whether the anti- corruption actions are strong enough to change the fundamental institutional constraints that give rise to the efficient grease effect of corruption in the first place. Market anticipations of a sufficiently strong anti-corruption campaign are thus likely to lead to positive returns.

Hypothesis 2. The announcement returns are lower for firms that produce luxury products compared to other firms.

Hypothesis 3. The announcement effects on state-owned, large, or politically connected firms depend on the relative strength of the grabbing-hand channel and the grease-of-wheel channel. An anticipation of sufficiently strong anti-corruption actions lowers the returns of state-owned, large, or politically connected firms relative to private, small, or non-connected firms.

The grabbing-hand and the grease-of-wheel channels predict conflicting effects on state-owned, large, or politically connected firms. Existing studies have well documented that those firms are treated favorably in China compared to private, small, or firms with no political connections (e.g., Dollar and Wei, 2007; Li et al., 2008; Song et al., 2011). On the one hand, they suffer less from government interventions and extractions at different levels. The beneficial effects of anti-corruption measures associated with eliminating the grabbing hands are thus smaller for those firms. On the other hand, state-owned, large, or connected firms also have access to cheaper inputs (capital, land, etc.) and are treated favorably in obtaining government services. As a result, they rely less on the grease-of-wheel channel, and, compared to private, small, or non-connected firms, they suffer less from anti-corruption measures that weakens such a channel. Nonetheless, it is important to note that this difference depends on whether the anti-corruption actions can change the underlying institutional constraints that give rise to the efficient grease effect of corruption in the first place. 
For a sufficiently strong anti-corruption campaign, eliminating the grabbing hands would be the dominant effect, and we would expect a lower announcement return for state-owned, large, or politically connected firms.

Hypothesis 4. The announcement return differentials between private and state-owned firms (small and large firms, or non-connected and connected firms) are smaller in provinces with better legal protections (a smaller grabbing-hand effect) or less developed factor markets (a larger grease-of-wheel effect).

In this hypothesis, we relate the return differentials between different types of firms to local institutions. Since private, small, or non-connected firms benefit (suffer) more than state-owned, large, or politically connected firms from the anti-corruption actions through the grabbing-hand (grease-of-wheel) channel, we expect the return differentials are smaller in provinces with better legal protections (a smaller grabbing-hand effect) or less developed factor markets (a larger grease- of-wheel effect).

\section{Data Description}

The main dataset used for our event study in this study covers all non-financial corporations listed on China's stock exchanges. It contains 2258 firms listed by the end of 2012. Stock returns and financial data are extracted from the China Stock Market and Accounting Research Database (CSMAR). In addition, we also make use of the Chinese Firm Registration Database that covers the universe of firms registered in China available for the years 2006 to 2015 to estimate the long-term effect on the entry of new firms. Finally, we employ a panel of Chinese listed firm data for the years $2007-2017$ to analyze the long-term effect on the scales of existing firms. ${ }^{7}$

\footnotetext{
${ }^{7}$ Since we need the estimated CAR for each to carry out the long-term DID analysis, the listed firm panel includes
} 
To empirically test our hypotheses, we construct several key firm level variables. First, we define a LUXURY dummy, which equals one if a company belongs to a high-end jewelry, high-end health care, or high-end liquor producer, or the high-end tailing industry, and zero otherwise. Next, we create a dummy variable for state ownership of a firm, labeled as SOE, which takes the value of one if the firm is ultimately controlled by the state government directly or through the equity chain, and zero otherwise. Following existing studies in the literature (Fan et al., 2007), we also construct a dummy variable to measure political connections (labeled as CONNECTED), which takes the value of one if a top management team member belongs to the People's Congress (PC) or the Chinese People's Political Consultative Conference (CPPCC). ${ }^{8}$ Firm size is defined as the logarithm of firm total assets. We also control for other variables at the firm level, including firm tax burden (labeled as TAX) and leverage ratio (labeled as LEVERAGE).

In addition, we also create measures of quality of local institutions using the province-level marketization index constructed by the National Economic Research Institute (NERI), (e.g., Du et al., 2008; Firth et al.,2009; Fan et al., 2010). This index is constructed using statistics of enterprise and household surveys. It covers five fields with a total of 23 basic indicators, ranging from 0 to 10 with higher scores indicating better quality of local institution. ${ }^{9}$ We make use of two of them to proxy two particular aspects of the quality of local institutions in China. The first indicator is the protection of producers' legitimate rights and interests. We expect that the grabbing-hand effect associate with corruption is weaker in provinces with stronger

\footnotetext{
only firms listed by the end of 2012. Firms listed after the event are not included.

${ }^{8}$ We also tried to use a simple count measure, and our results are robust to this alternative measure.

9 See Fan et al. (2010) for details of this index.
} 
legal protections. The second indicator we consider is the degree of factor market development. In provinces with more developed and market-oriented factor markets, the gains from paying bribes (i.e., the grease-of-wheel effects) are weaker. We also include other provincial variables, including GDP per capita and education expense as control variables. Summary statistics are reported in Table 1. Details of variable definitions and data sources are shown in Appendix B.

[Insert Table 1 around Here]

\section{Empirical Results}

\subsection{The Event Date}

We employ an event study approach to examine the reactions of stock market to the inspection announcement. To implement an event study, we first need to identify a clear event date. The CCDI launched a total of four rounds of anti-corruption inspections in years 2013 and 2014. Before each round of inspection, the CCDI would initiate a deployment meeting, in which the provinces to be inspected are announced. Appendix A lists the announcement dates and provinces to be inspected in each round. For an event study to be valid, the event must be unexpected news. Therefore, we pick the announcement of the first-round inspection as our event date. The effective date is May 17, 2013.

We also check whether the inspection announcement is the most relevant news during the event periods. In Table 2, we report the Baidu Index, an indicator for Baidu search scale, for each top political event in the inspected month (May 2013). The anti-corruption inspection is clearly the most relevant news.

[Insert Table 2 around Here] 


\subsection{Market Responses}

To examine the market responses to the event, we first estimate a market model over a 180-day estimation window ending 11 days before the announcement date. A value-weighted average return of all stocks in our sample is adopted as the market return. We then calculate cumulative abnormal returns (CARs) over an 11-day $(-5,5)$ event window centered on the inspected announcement date (May 17, 2013) and test their statistical significance. Reported in Table 3, the average of the CARs is positive and significantly different from zero. We also report the ratio of firms with negative CARs to the total number of firms. We find only 774 out of 2258 firms experienced a decline in their stock prices in the 11-day event window. Our results thus indicate that overall market participants view this anti-corruption inspection as positive news. Quantitatively, the estimated average CARs suggest that the market gains $2.818 \%$ in the 11-day event window. This finding is consistent with our first hypothesis that sufficiently strong anti-corruption actions in equilibrium can change the underlying institutional constraints that give rise to the efficient grease effect of corruption in the first place.

\section{[Insert Table 3 around Here]}

To establish the robustness of our results, we consider a variety of alternative market benchmarks. Following Ji and Wei (2014), an equal-weighted average return and Hushen 300 index are considered as alternative market benchmarks. In addition, we also consider a three-factor model (i.e., adding the size factor and book-to-market factor as two new factors in addition to the market factor). As shown in Table 3, our results are not affected by the choice of the market benchmark.

Another way to check the sensitivity of our results is to choose alternative event windows. To deal with the issue that eleven days may not be long enough to absorb 
the inspection news, we also try three longer event windows, a 16-day window, a 21-day window, and a 31-day window. As shown in the last three rows in Table 3, using alternative event windows does not alter our finding either. The estimated CARs are all positive and significant.

\subsection{Firm Heterogeneity}

\subsubsection{Benchmark results}

The above results indicate that overall stock market responded positively to the announcement of anti-corruption inspections by the CCDI. In this subsection, we explore further the heterogeneous effects of anti-corruption inspections across different firms. Our simple conceptual framework and the hypotheses developed in Section 3 suggest that the effects of combating corruption on individual firms depend on firm characteristics and local institutions. We examine firms' heterogeneous responses by regressing the estimated firm CARs obtained from the event study on firm and province characteristics. Specifically, we consider the following model:

CAR $_{i}=\alpha+\beta_{1}$ Luxury $_{i}+\beta_{2}$ SOE $_{i}+\beta_{3}$ Size $_{i}+\beta_{4}$ Connected $_{i}+\gamma C_{i}+\varphi_{j}+\varphi_{k}$

where CAR is cumulative abnormal return of each firm. LUXURY and SOE are dummies for firms that produce luxury products and firms with state ownership, respectively. Specifically, LUXURY equals one is a firm is a high-end jewelry, high-end health care, or high-end liquor producer, or belongs to the high-end tailing industry, and SOE takes the value of one if a firm is controlled by local or national governments. SIZE is a measure of firm size and is defined as the logarithm of firm total assets. CONNECTED is a dummy variable for political connections, which takes the value of one if a top management team member belongs to the People's congress or CPPCC. We also control for other variables at the firm level, including firm tax 
burden (TAX) and leverage ratio (LEVERAGE). $\varphi_{j}$ and $\varphi_{k}$ are industry and province fixed effects, respectively.

Table 4 shows the benchmark results using the market model and an 11-day event window. In Column (1), we perform a preliminary analysis without controlling for industry or province fixed effects. In Column (2), we add industry fixed effects. In both columns, we also create an INSPECTED dummy variable for provinces to be inspected in the first round of anti-corruption inspection and include it in the regressions. The omitted group thus consists of provinces not included in the first-round inspection. Both regressions yield favorable results supporting our Hypothesis 2, which is based on the market demand channel illustrated in the simple theoretical framework. The estimated coefficient on the LUXURY dummy is negative and significant. Compared to other firms, firms that produce luxury products have a lower return of $3.19 \%$. We also find that, interestingly, the INSPECTED dummy is statistically insignificant and quantitatively very small in each column, indicating that the announcement of the anti-corruption campaign has a nationwide effect. While the announcement only informs market participates of the five provinces to be inspected in the first round, the market well anticipates that all provinces will be inspected eventually in the future.

Our simple model does not make an unambiguous prediction on the differential effect of fighting corruption on private and state-owned firms. On the one hand, private firms are more subject to government extractions. On the other hand, the grease-of-wheel channel also has greater impact on private firms as their operations are often more sensitive to government service provision. Anti-corruption measures thus can have an ambiguous effect on the return differential between private and state-owned firms. However, as emphasized by Kaufman and Wei (1999), in a general 
equilibrium, a strong enough combat on corruption can change the institution constraints giving rise to the grease of wheel channel in the first place. If this is the case, then we should expect a higher return for private firms. Our results are indeed in favor of this speculation. We find that state-owned firms have significantly lower anti-corruption announcement returns than private firms. This finding is also consistent with those documented by Lin, Morck, Yeung, and Zhao (2016) and Li, Wang, and Zhou (2017) that non-SOEs benefit more from the anti-corruption actions. Similarly, we also find that the announcement returns are significantly lower for large or politically connected firms as the estimated coefficients on firm size and the political connection dummy are both significantly negative. The evidence from the return differentials between private and state-owned (small and large, or non-connected and connected) firms thus is consistent with our third hypothesis.

In the last column of Table 4, we control for both industry and province fixed effects. The INSPECTED dummy is absorbed by the inclusion of the province fixed effects. We, however, still find consistent results that the announcement returns are significantly lower for luxury goods producers, state-owned, large, or politically connected firms.

\section{[Insert Table 4 around Here]}

\subsubsection{Robustness checks}

In this subsection, we conduct a series of sensitivity analyses to ensure the robustness of our results. In Table 5, we conduct two sets of robustness checks. The first set of robustness checks is to consider alternative event winds. Specifically, we consider a $(-5,10)$, a $(-10,10)$, and a $(-10,20)$ event window and report the results in Columns (1)-(3), respectively. Next, in Columns (4)-(6), we try different market benchmarks. In Column (4), we change the market model to a three-factor model (i.e., 
adding the size factor and book-to-market factor as two additional factors). In Columns (5) and (6), we use value weighted average return and Hushen 300 index as market benchmarks, respectively. Using alternative event winds or market benchmarks does not change our main findings. The estimated coefficients on SOE, LUXURY, SIZE, and CONNECTED are still negative and mostly significant.

[Insert Table 5 around Here]

Table 6 considers further the robustness of our results to alternative measures to the three key firm characteristics, ownership, size, and political connections. Column (1) employs an alternative measure of state-owned firms dummy based on firms' registration type rather than actual controller. In Column (2), we use number of employees (in natural log) to proxy for firm size. Finally, we use a count measure defined as $\ln (1+$ number of connected board directors $)$ as an alternative measure of political connections, where connected board directors are those who are current or former member of the people's congress or the CPPCC. Using alternative measures of firm characteristics does not affect our results either. We continue to find a significantly lower announcement return for state-owned, large, or connected firms.

[Insert Table 6 around Here]

\subsection{The role of local institutions}

So far, we have shown that the effects of China's anti-corruption campaign vary across firms. Here we explore further the role of local institutions in determining the return differentials across different types of firms. As discussed in Hypothesis 4, to the extent local institutions affect the grabbing-hand and the grease-of-wheel channels, they also influence the return differentials. For example, compared to private firms, SOEs benefit less from fighting corruption through the grabbing-hand channel. This differential, however, is smaller in provinces with better legal protections of firm 
rights and interests where the grabbing hand effect is weaker. On the other hand, the impact of the grease-of-wheel channel depends also on local institutions. Our model suggests that the grease-of-wheel channel works through its impact on firms' marginal costs. Its impact thus is weaker in provinces where factor markets are more developed and market-oriented (so that governments have less influence on factor prices and allocations). While the adverse effect of fighting corruption through the grease-of-wheel channel is larger for private firms, the differential should be smaller in provinces with more developed factor markets. Similar arguments also apply to the comparisons between large and small firms, or connected and non-connected firms. To empirically test this hypothesis, here we employ two measures of institutions at the province level constructed by a non-government research institute in China, the National Economic Research Institute (NERI). The first one is an index of legal protections, PROTECTION, and a higher value means better legal protections of firm rights and interests. The second index, FACTORMKT, measures the degree of factor market development. A higher value of this index means the government plays a smaller role in determining the allocations or prices of financial resources, labor, and patents, etc.

We then re-estimate the benchmark model with industry and province fixed effects (the last regression in Table 4) but adding the interaction terms between firm characteristics and local institution measures as additional regressors. The results are reported in Table 7. Column (1) shows the interaction effects between the two institution variables and the SOE dummy. The evidence is in favor of our hypothesis. The estimated coefficient on interaction term SOE*PROTECTION is positive and statistically significant, while that on SOE*FACTORMKT significantly negative. The two significant interaction terms suggest that local institutions do play a role in 
determining the effects of fighting corruption across firms. Specifically, the first interaction term indicates that the return differentials between private and state-owned firms due to the grabbing-hand effect declines with the degree of local legal protections of firm rights. The second interaction effect suggests that the adverse effect of anti-corruption actions on private firms is smaller in provinces with more developed factor markets. Columns (2) and (3) report the interaction effects between the local institution variables and firm size and political connections, respectively. The results are also consistent with Hypothesis 4. In Column (2), we find that a positive and significant estimated coefficient on the interaction term between firm size and PROTECTION, but a negative and significant coefficient on the interaction term between firm size and FACTORMKT. The two interaction terms in Column (3) also have correct signs. CONNECTION*PROTECTION has a $t$-value of 1.5 , and CONNECTION *FACTORMKT is statistically significant at the 5\% level.

[Insert Table 7 around Here]

\subsection{Long-term impacts}

So far, we have shown that our results from the event study analysis are consistent with the theoretical predictions. A caveat of the event study approach is that it relies on the market efficiency assumption. If the market efficiency assumption is invalid, then our event study results may not capture the true effects of anti-corruption. To address this concern, here we provide further evidence on firms' long-term performance. Since corruption can lead to both less entry on the extensive margin, and to smaller scale on the intensive margin (e.g., Klitgaard, 1991; La Porta, et al., 1999; Shleifer and Vishny, 1993), we examine the long-term effects of the anti-corruption campaign on both margins. If our event study results are valid, we should expect industries with higher average CARs during the event window 
subsequently to have more entries of new firms on the extensive margin. Similarly, on the intensive margin, we should also expect that firms with higher CARs during the event window to expand in their scales after the anti-corruption campaign.

\subsubsection{Long-term impact on the extensive margins}

We first provide evidence on the long-term effect of entry of new firms. To examine the long-term effect on firm entry, we make use of the Chinese Firm Registration Database that covers the universe of firms registered in China available for the years 2006 to $2015 .{ }^{10}$ We consider a generalized difference-in-differences approach and estimate the following empirical model:

Entry $_{s t}=\beta$ Post $_{t} \times C A R_{s}+\alpha_{s}+\alpha_{t}+\varepsilon_{s t}$

where the dependent variable, Entry ${ }_{s t}$, is the total number of newly registered firms (in natural $\log$ ) at the industry-year level. Our variable of interest is the interaction term between a post-anti-corruption (year 2013 and after) dummy and the average industry-level CAR during the event window. A positive and significant coefficient $\beta$ would suggest that industries that had higher CARs during the event window indeed experience more entries of new firms during the post-event period. We also control for industry fixed effects, $\alpha_{s}$, and year fixed effects, $\alpha_{t}$, in our regressions.

The results are reported in Table 8. Column (1) shows the benchmark results where we calculate the CARs using the benchmark market model and an eleven-day, $(-5$ 5), event window. For robustness, we also consider alternative event windows in Columns (2) - (4) and alternative market benchmarks in Columns (5) - (7). The results are quite robust. The estimated coefficients on the interaction term are found to be positive and significant in all regressions.

[Insert Table 8 around Here]

\footnotetext{
${ }^{10}$ In China, all firms are required to register with the General Administration of Industry and Commerce.
} 
In Table 9, we further examine the long-term effects on firm entry at the more disaggregate province-industry level. We compute using the registration data the total number of entries at the province-industry-year level (in natural log), Entry $y_{p s t}$, and estimate the following model:

Entry $_{p s t}=\beta$ Post $_{t} \times C A R_{p s}+\alpha_{p}+\alpha_{s}+\alpha_{t}+\varepsilon_{p s t}$

where $C A R_{p s}$ is the average CAR at the province-industry level, and $\alpha_{p}$ is the province fixed effect. We repeat the exercises in Table 8 using more disaggregate province-industry level data in Columns (1) - (7). In Column (8), we use the more stringent province-industry fixed effects to replace province fixed effects and industry fixed effects. The results are quite similar. We continue to find that higher returns during the event window are associated with more subsequent entries of new firms. ${ }^{11}$

[Insert Table 9 around Here]

\subsubsection{Long-term Impact on the intensive margins}

Since (anti-)corruption affects not only firm entry on the extensive margin but also leads to smaller scale on the extensive margin, we also examine the long-term effect of the anti-corruption campaign on firm size of existing firms using a similar generalized DID approach. Specifically, we estimate the following empirical model using the Chinese listed firm data for the years 2007 - 2017:

Outcome $_{i t}=\beta$ Post $_{t} \times$ CAR $_{i}+\delta$ Post $_{t} \times$ Controls in initial year $i+\alpha_{i}+\alpha_{t}+$ $\varepsilon_{i t}$

The dependent variable is firm size measured by total asset (in natural log). The first term on the right-hand side is our variable of interest - an interaction term of firm CAR during the event window and an indicator variable (Post) for years 2013 and

\footnotetext{
11 We have also tried to control for the interaction terms between initial year industry characteristics, such as log employment, log assets, productivity, in (7) and (8) using industry-level data from China Statistical Year Book. The sample size becomes smaller due to missing industry-level data, but our results hold strongly.
} 
after, which captures the relative change in the outcome variable among firms with differential exposure to the change in anti-corruption after versus before the event year. The second term on the right-hand side represents a series of initial (2009) firm attributes that proxy for investment opportunities and firms' ability to finance future investments, also interacted with the post anti-corruption dummy. ${ }^{12}$ These attributes include current asset, leverage, market-to-book ratio (MTB), cash flow and cash holding. We also include firm and year fixed effects and cluster the standard errors at the firm level.

\section{[Insert Table 10 around Here]}

Table 10 shows the estimation results. Column (1) illustrates the benchmark results using the 11-day event window and the benchmark market model. Robustness checks based on alternative event windows and market benchmarks are provided in the rest columns. We find that the estimated coefficients on the interaction term between the post dummy and the CAR are all positive and statistically significant. The results suggest that firms with higher event CARs indeed experienced faster expansion in scales after the anti-corruption campaign. Overall, the long-term effects obtained from the DID approach are consistent with the theoretical predictions on the extensive and intensive margins and are also consistent with the event-study results.

\subsection{Evidence on the endogenous grits effect}

A key element in our equilibrium analysis of the economic consequences of anti-corruption is the endogenous grits effect (see Section 3). In our theoretical framework, the bureaucrats can choose the "grits" of the bureaucracy that affect the firm's marginal cost of production. For sufficiently strong anti-corruption actions, the bureaucrats may endogenously choose to switch from a high regulatory regime to a

\footnotetext{
12 For firms that enter the sample after 2009, we use their attributes upon entry.
} 
low regulatory regime if taking bribes is too costly. Our findings in Sections $5.2-5.5$ suggest that a change in the underlying institutional constraints indeed occurred in China after the strong anti-corruption campaign as proxied by the CCDI announcement. Here we provide some direct evidence on the endogenous grits effect.

We present two pieces of direct evidence on institutional changes plausibly related to regulatory regime of doing business in China. First, we examine the commonly-used "Ease of Doing Business" index constructed by the World Bank to present some suggestive graphical evidence. The Ease of Doing Business index presents quantitative indicators on business regulations and the protection of property rights that can be compared across 190 economies. ${ }^{13}$ It ranks countries based on how the regulatory environment is conducive to business operation and protections of property rights. A higher rank (a low numerical value) indicates better regulations for businesses and stronger protections of property rights. Figure 1 shows the global ranking for China for the years 2008-2019. Its rank was around 90 in the first several years and reached an all-time high of 99 in 2012. After the anti-corruption campaign, however, there is a clear pattern that China's rank started to improve. Its rank improved to 83 in 2014, and in 2019, it reached and a record low of 31.

Next, we present evidence using the overall marketization index constructed by the National Economic Research Institute (NERI). ${ }^{14}$ The overall marketization index captures the institutional development in China in five areas, including the relationship between governments and the market, the development of non-state-owned sector, the development of product market, the development of factor market, and legal protection. A higher index value indicates a better institutional environment for business. This index is available at the Chinese province 
level for the years 2008 - 2016. A simple before-and-after comparison shows that the national average value of this index increased from 5.57 in the pre-anti-corruption (2008-2012) period to 6.48 in the post-anti-corruption (2013-2016) period. Given that the mean of this index for the whole sample period is only 5.97 , this is a fairly large increase.

We also use this province-year panel to conduct a regression analysis. Specifically, we regress the marketization index on a post anti-corruption dummy that takes the value of 1 for the years 2013 and after, controlling for province fixed effects. The regression results are reported in Table 11. They are consistent with the evidence obtained from the Ease of Doing Business index. We find that the estimated coefficient on the post anti-corruption dummy is positive and statistically significant, indicating a better business environment in China after the anti-corruption campaign. Quantitatively, the estimated effect is also substantial. The estimated coefficient on the post anti-corruption dummy is 0.91 , which is $15.2 \%$ of the sample mean value of the marketization index.

\section{Conclusion}

China's recent anti-corruption campaign provides a unique opportunity to study the economic consequences of large-scale government anti-corruption effects in developing countries where corruption is a central issue. We first provide a simple theoretical framework to illustrate the four potential channels through which anti-corruption policy can affect firms: the "grabbing hand" effect, the "grease of the wheel" effect, the demand effect, and the endogenous grits effect. It predicts an ambiguous effect of combating corruption on an individual firm's performance depending on firm characteristics and local institutions. 
In the empirical part of our study, we use an event study approach to examine the market expected effects of the anti-corruption campaign. Specifically, we focus on market responses to the symbolic event of this campaign, the announcement of anti-corruption inspections to be conducted by the CCDI of the CCP. We find robust evidence that stock market responded significantly positively to the announcement. The estimated cumulative abnormal returns range from $2.4 \%-5.3 \%$ depending on different event windows or methods.

Further regression analysis reveals that the effects are heterogeneous across firms. Consistent with a market demand channel, stock prices of luxury good producers fall after the announcement. The announcement returns are also found to be significantly smaller for SOEs, large firms, or firms with established political connections. Moreover, we show that the return differentials between private firms and SOEs, as well as those between small and large firms or between connected and non-connected firms, are smaller in provinces with better legal protections of firm rights and interests (i.e., weaker grabbing-hand effect), but larger in provinces with more developed and market-oriented factor markets (i.e., a weaker grease-of-wheel effect). These regression results along with an overall positive market response are strongly in favor of the general equilibrium view. They suggest that, for a strong anti-corruption campaign, the beneficial effect associated with eliminating governments' grabbing hands on average dominates the potential adverse effect associated the potential loss of efficiency grease.

In addition to short-term event study analysis, we also use a generalize difference-in-differences approach to investigate the long-term effects of the anti-corruption campaign. Consistent with the event-study results, we find that higher CARs during the event window are associated with significantly more subsequent 
entries of new firms and expansions of existing firms. Finally, we also provide direct evidence on the endogenous grits effect that is crucial to our equilibrium analysis of anti-corruption.

\section{References}

[1] Bardhan, Pranab (1997). "Corruption and Development: A Review of Issues." Journal of Economic Literature, Vol. 35, No. 3, 1320-1346.

[2] Beck, P. J., and M.W. Maher (1986). "A Comparison of Bribery and Bidding in Thin Markets.” Economics Letters, 20(1), 1-5.

[3] Berkowitz, Daniel, Chen Lin and Sibo Liu (2015). "De-Politicization and Corporate Transformation: Evidence from China's Anti-Corruption Reforms." Working Paper, University of Pittsburgh.

[4] Cai, H., Fang, H., Xu, L.C. (2011). "Eat, Drink, Firms and Government: An Investigation of Corruption from Entertainment and Travel Costs of Chinese Firms." Journal of Law and Economics, 54, 55-78.

[5] Djankov, Simon, Rafael La Porta, Florencio Lopez-De-Silanes, and Andrei Shleifer. (2012) “The Regulation of Entry.” Quarterly Journal of Economics, 117, $1-37$.

[6] Dollar, D., and S.-J. Wei (2007). "Das (Wasted) Kapital: Firm Ownership and Investment Efficiency in China.” NBER Working Paper No. 13103.

[7] Du, J., Lu, Y., Tao, Z. (2008). “Economic Institutions and FDI Location Choice: Evidence from US Multinationals in China." Journal of Comparative Economics, $36,412-429$.

[8] Fan, G., Wang, X., Zhu, H. (2010). 'NERI Index of Marketization of China's Provinces: 2011 Report” (in Chinese). Economic Science Press, Beijing

[9] Fang, Hanming, Quanlin Gu, and Li-An Zhou (2014). “The Gradients of Power: Evidence from the Chinese Housing Market.” NBER Working Paper No. 20317.

[10]Fisman, Ray and Miram A. Golden (2017). Corruption: What Everyone Needs to Know. Oxford University Press.

[11]Fisman, Ray and Jacob Svensson (2007). "Are Corruption and Taxation Really 
Harmful to Growth? Firm Level Evidence.” Journal of Development Economics, 83(1), 63-75.

[12]Fisman, Ray and Yongxiang Wang (2015). "Corruption in Chinese Privatizations." Journal of Law, Economics, and Organization, 31(1), 1-29.

[13]Fisman, R., and Wei, S. J. (2004). "Tax Rates and Tax Evasion: Evidence from Missing Imports in China." Journal of Political Economy, 112(2): 471-496.

[14]Firth, M., Lin, C., Liu, P., Wong, S.M. (2009). "Inside the Black Box: Bank Credit Allocation in China's Private Sector.” Journal of Banking and Finance, $33,1144-1155$.

[15]Huntington, Samuel P. (1968). Political Order in Changing Societies, Yale University Press.

[16]Javorcik, B. S., and Wei, S. J. (2009). "Corruption and Cross-Border Investment in Emerging Markets: Firm-Level Evidence.” Journal of International Money and Finance, 28(4), 605-624.

[17]Ji, L., and Wei, S. J. (2014). "Learning from a Puzzle: When Can Stronger Labor Protection Improve Productivity.” Working Paper.

[18]Kaufmann, D., and Wei, S. J. (1999). “Does 'Grease Money' Speed Up the Wheels of Commerce?" NBER Working Paper No. 7093.

[19]Klitgaard, R. (1991). "Gifts and Bribes.” Strategy and Choice, 419-435.

[20]La Porta, R., Lopez-de-Silanes, F., Shleifer, A., and Vishny, R. (1999). “The Quality of Government." Journal of Law, Economics, and Organization,15(1), 222-279.

[21]Leff, Nathaniel H. (1964). "Economic Development through Bureaucratic Corruption." The American Behavioral Scientist, 8(2), 8-14.

[22]Li, H., Meng, H., Wang, Q. and Zhou L.A. (2008). "Political Connections, Financing and Firm Performance: Evidence from Chinese Private Firms." Journal of Development Economics, 87(2), 283-299.

[23]Lien, D. H. D. (1986). “A Note on Competitive Bribery Games.” Economics Letters, 22(4), 337-341.

[24]Lin, Chen, Randall Morck, Bernard Y. Yeung, and Xiaofeng Zhao (2016). 
“Anti-Corruption Reforms and Shareholder Valuations: Event Study Evidence from China.” NBER Working Paper No. 22001, forthcoming, Journal of Financial Economics.

[25]Mauro, Paolo (1995). “Corruption and Growth.” Quarterly Journal of Economics, $110(3), 681-712$.

[26]Méon, P. G., and Sekkat, K. (2005). "Does Corruption Grease or Sand the Wheels of Growth?” Public Choice, 122(1-2), 69-97.

[27]Mo, P. H. (2001). “Corruption and Economic Growth.” Journal of Comparative Economics, 29(1), 66-79.

[28]Qian, Nancy, and Jaya Wen (2015). “The Impact of Xi Jinping's Anti-Corruption Campaign on Luxury Imports in China.” Preliminary Draft, Yale University.

[29] Shleifer, A., Vishny, R. (1993). “Corruption.” Quarterly Journal of Economics, $108,599-617$.

[30] Song Z, Storesletten K, Zilibotti F. (2011). "Growing Like China." American Economic Review, 101(1), 196-233.

[31]Wei, S. J. (2000a). "How Taxing is Corruption on International Investors?" Review of Economics and Statistics, 82(1), 1-11.

[32]Wei, S. J. (2000b). "Local Corruption and Global Capital Flows.” Brookings Paper on Economic Activities, 2, 303-354.

[33]Wei, S. J. (2001). "Negative Alchemy? Corruption, Composition of Capital Flows and Currency Crises." NBER Working Paper No. 8187. 
Appendix A. Announcement of Inspection Dates for Various Provinces

\begin{tabular}{|c|c|c|c|}
\hline $\begin{array}{l}\text { Round of } \\
\text { Inspection }\end{array}$ & Provinces & Effective Date & $\begin{array}{l}\text { Number of listed firms } \\
\text { in inspected provinces }\end{array}$ \\
\hline $1 \mathrm{st}$ & $\begin{array}{l}\text { Chongqing, Guizhou, Jiangxi, } \\
\text { Inner Mongolia, Hubei }\end{array}$ & May 17,2013 & 183 \\
\hline 2nd & $\begin{array}{l}\text { Anhui, Hunan, Jilin, } \\
\text { Yunnan, Shanxi, Guangdong } \\
\text { Xinjiang, Liaoning, Beijing, }\end{array}$ & $\begin{array}{c}\text { October } 23, \\
2013\end{array}$ & 575 \\
\hline $3 \mathrm{rd}$ & $\begin{array}{l}\text { Ningxia, Shandong, Tianjin, } \\
\text { Henan, Gansu, Hainan, Fujian }\end{array}$ & March 15, 2014 & 677 \\
\hline 4 th & $\begin{array}{l}\text { Guangxi, Shanghai, Qinghai, } \\
\text { Tibet, Zhejiang, Hebei, Shanxi, } \\
\text { Heilongjiang, Sichuan, Jiangsu }\end{array}$ & July 16, 2014 & 850 \\
\hline
\end{tabular}




\section{Appendix B. Variable Definitions and Data Sources}

- Stock Market Data: Daily comparable closing returns (with cash dividend reinvested) and daily aggregated market returns without cash dividend (current value weighted) are denoted as stock and market returns, respectively. Data Source: CSMAR.

- Inspected: A dummy variable equals one if the firms are registered in the inspected provinces (usually located in the same provinces), and zero otherwise. Data Source: CSMAR.

- Luxury: A dummy variable to indicate luxury products, equals one if the list company belongs to jewelry industry, high-end retailing industry, high-end health care products industry, high-end liquor industry, etc., and zero otherwise. Data Source: CSMAR.

- SOE: A dummy variable equals one if the firm is ultimately controlled by the state government directly or through the equity chain, and zero otherwise. Data Source: CSMAR.

- SOE 2: A dummy variable equals one if a firm is registered as a state-owned firm. Data Source: CSMAR.

- Size: The logarithm of total assets. Data Source: CSMAR.

- Size_2: The logarithm of number of employees. Data Source: CSMAR.

- Connected: A dummy variable equals one if a top management team member (including CEO) belongs to People's Congress or CPPCC at any level, and zero otherwise. Data Source: CSMAR.

- Connected_2: A count variable that count the number of total political ties (membership of PC or CPPCC). Data Source: CSMAR.

- Tax: The ratio of total tax to the total sales. Data Source: CSMAR.

- Leverage: The ratio of total debts to total assets. Data Source: CSMAR.

- PCGDP: The logarithm of GDP of a province. Data Source: National Bureau of Statistics of China.

- Education: The ratio of education expenditures to GDP of a province. Data Source: National Bureau of Statistics of China. 
- Protection: Protection denotes the protection of producer's legitimate rights and interests, which is measured by an index of court's efficiency in resolving legal cases (economic disputes). The higher the value, the stronger the legal protection. Data Source: National Economic Research Institute (NERI).

- Factor Market: Factor market represents factor market development, which is comprised by the degree of financial sector marketization, the degree of foreign capital importation, the degree of labor movement, and the marketization of technological achievements. The higher the score, the more developed the factor market. Data Source: National Economic Research Institute (NERI). 


\section{Appendix C. Eight-Point Regulation: December 4, 2012}

The Eight-Point Regulation issued on December 4, 2012, made explicit requirements on how Political Bureau members should improve their work style in eight aspects, focusing on rejecting extravagance and reducing bureaucratic visits, meetings and empty talk. The political bureau, which has 25 members, includes the top decision-makers, such as State leaders, Party chiefs of several key provincial-level regions, ministers and top army officials.

\section{1. (Keep Close Contact with the Grassroots, but Prohibit Inspection Tours)}

Leaders must keep in close contact with the grassroots. They must understand the real situation facing society through in-depth inspections at grassroots. Greater attention should be focused on places where social problems are more acute, and inspection tours must be carried out more thoroughly. Inspection tours as a mere formality should be strictly prohibited. Leaders should work and listen to the public and officials at the grassroots, and people's practical problems must be tackled. There should be no welcome banner, no red carpet, no floral arrangement or grand receptions for officials' visits.

2. (Prohibit Empty Meetings) Meetings and major events should be strictly regulated, and efficiency improved. Political Bureau members are not allowed to attend ribbon-cutting or cornerstone-laying ceremonies, or celebrations and seminars, unless they get approval from the CPC Central Committee. Official meetings should get shortened and be specific and to the point, with no empty and rigmarole talks.

3. (Reduce Official Documents) The issuing of official documents should be reduced.

4. (Restrict Official Visits Overseas) Officials' visits abroad should only be arranged when needed in terms of foreign affairs with fewer accompanying members, and on most of the occasions, there is no need for a reception by overseas Chinese people, institutions and students at the airport.

\footnotetext{
15 The material in this appendix is from: http://cpcchina.chinadaily.com.cn/2012-12/05/content_15991171.htm
} 
5. (Leaders' Travel by Car Should Follow Traffic Rules) There should be fewer traffic controls when leaders travel by cars to avoid unnecessary inconvenience to the public. There should be fewer traffic controls arranged for the leaders' security of their trips to avoid unnecessary inconvenience to the public.

6. (Media Should Report Only Official Events with Real News Value) The media must not report on stories about official events unless there is real news value. The regulations also ban worthless news reports on senior officials' work and activities and said such reports should depend on work needs, news value and social effects.

7. (Leaders Should Not Publish Without the Approval from the Central Leadership) Leaders should not publish any works by themselves or issue any congratulatory letters unless an arrangement with the central leadership has been made. Official documents without substantial contents and realistic importance should be withheld. Publications regarding senior officials' work and activities are also restricted.

8. (Leaders Should Live a Thrifty Lifestyle) Leaders must practice thrift and strictly follow relevant regulations on accommodation and cars. 
Figure 1. Ease of doing business in China (Global Ranking)

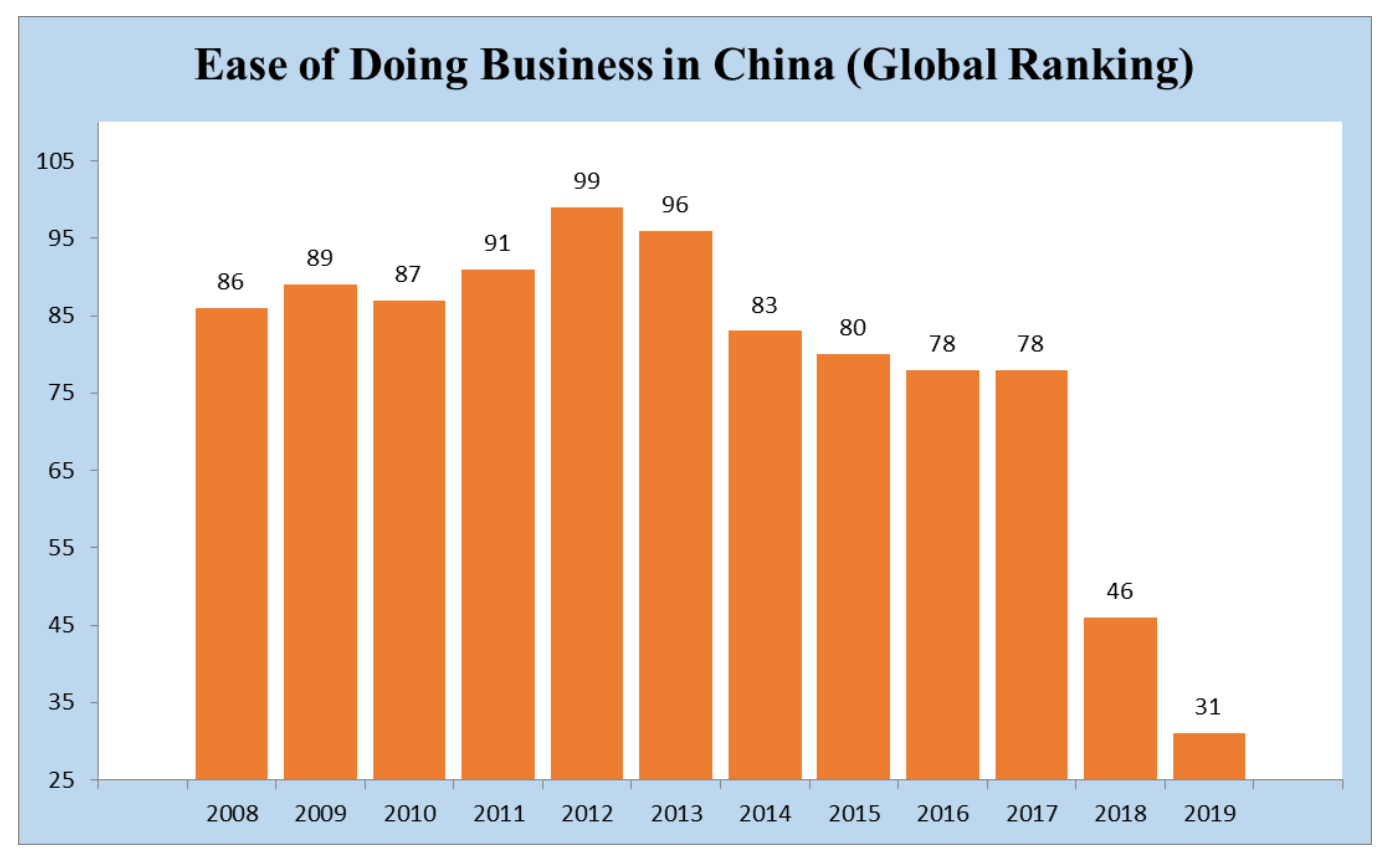


Table 1. Summary Statistics

\begin{tabular}{|l|c|c|c|c|}
\hline Variable & Mean & Std. Dev. & Min & Max \\
\hline Inspected & 0.0779 & 0.2681 & 0 & 1 \\
\hline Luxury & 0.0120 & 0.1087 & 0 & 1 \\
\hline Leverage & 0.4343 & 0.2841 & 0.0110 & 7.9952 \\
\hline SOE & 0.3716 & 0.4833 & 0 & 1 \\
\hline SOE_2 & 0.4141 & 0.4927 & 0 & 1 \\
\hline Connection & 0.2857 & 0.4518 & 0 & 1 \\
\hline Connection_2 & 0.2420 & 0.4072 & 0 & 2.4849 \\
\hline FactorMarket & 6.2583 & 1.3851 & 2.2800 & 8.5200 \\
\hline Protection & 5.6533 & 1.5910 & -1.9100 & 8.9300 \\
\hline Ln_Asset & 21.8237 & 1.3131 & 15.7294 & 28.4052 \\
\hline Tax & 0.0376 & 0.0468 & -0.2333 & 0.3637 \\
\hline Ln_Labor & 7.5322 & 1.3402 & 1.6094 & 13.2147 \\
\hline CAR (-5, 5) & 0.0282 & 0.0707 & -0.2938 & 0.4860 \\
\hline CAR (-5,10) & 0.0331 & 0.0843 & -0.3262 & 0.5457 \\
\hline CAR (-10,10) & 0.0460 & 0.1020 & -0.2976 & 0.7388 \\
\hline CAR (-10,20) & 0.0543 & 0.1393 & -0.7772 & 0.8167 \\
\hline 3_Factor CAR (-5,5) & 0.0332 & 0.0706 & -0.2984 & 0.4806 \\
\hline Total Value CAR (-5, 5) & 0.0243 & 0.0706 & -0.2962 & 0.4817 \\
\hline Hushen 300 CAR (-5,5) & 0.0422 & 0.0710 & -0.2828 & 0.4998 \\
\hline Ease of Doing Business Ranking & 78.6667 & 20.1284 & 31 & 99 \\
\hline Overall marketization index & 5.9736 & 2.0244 & -0.23 & 10 \\
\hline
\end{tabular}


Table 2. Most Relevant News in May 2013.

\begin{tabular}{cc}
\hline \hline Big Events & Highest Baidu Index \\
\hline World Horticultural Exposition & 506 \\
Anti-corruption Inspection & $\mathbf{1 6 0 7}$ \\
South Asia Expo & 468 \\
Railway System Reform & 842 \\
Regulations of Food Safety & 181 \\
\hline \hline
\end{tabular}

Notes: Baidu is the most popular local search engine in China. The Baidu Index is an indicator reflecting the search scale of one specific event within a given period. Here we report the Baidu index for top political events (top search phrases) in the inspected month (May 2013). The bigger the number, the larger the search scale of the event. 
Table 3. Stock Market Reactions

\begin{tabular}{lcc}
\hline \multicolumn{1}{c}{ Model } & Average CAR & Negative Firms/All Firms \\
\hline CAR $(-5,5)$ & $0.0282^{* * *}$ & $774 / 2258$ \\
Three factor CAR $(-5,5)$ & $0.0332^{* * *}$ & $648 / 2258$ \\
Total value CAR $(-5,5)$ & $0.0243^{* * *}$ & $850 / 2258$ \\
Hushen300 CAR $(-5,5)$ & $0.0422^{* * *}$ & $516 / 2258$ \\
CAR $(-5,10)$ & $0.0331^{* * *}$ & $723 / 2258$ \\
CAR $(-10,10)$ & $0.0460^{* * *}$ & $707 / 2258$ \\
CAR $(-10,20)$ & $0.0543^{* * *}$ & $828 / 2258$ \\
\hline \hline
\end{tabular}

Notes: ${ }^{*},{ }^{*}$ and ${ }^{* * *}$ denote the 10,5 and 1 percent significance levels, respectively. 
Table 4. Benchmark Regressions

\begin{tabular}{|c|c|c|c|}
\hline Dep $=$ CARs & (1) & $(2)$ & (3) \\
\hline Inspected & $\begin{array}{l}-0.0073 \\
(-1.701)\end{array}$ & $\begin{array}{l}-0.0045 \\
(-1.324)\end{array}$ & \\
\hline Luxury & $\begin{array}{c}-0.0366^{* * *} \\
(-3.305)\end{array}$ & $\begin{array}{c}-0.0321 * * \\
(-2.874)\end{array}$ & $\begin{array}{c}-0.0334 * * * \\
(-3.371)\end{array}$ \\
\hline SOE & $\begin{array}{c}-0.0085 * \\
(-2.003)\end{array}$ & $\begin{array}{c}-0.0061 * * \\
(-2.466)\end{array}$ & $\begin{array}{c}-0.0068^{* *} \\
(-2.347)\end{array}$ \\
\hline Size & $\begin{array}{c}-0.0048 * * * \\
(-4.351)\end{array}$ & $\begin{array}{c}-0.0034 * * * \\
(-4.185)\end{array}$ & $\begin{array}{c}-0.0038 * * * \\
(-4.910)\end{array}$ \\
\hline Connected & $\begin{array}{c}-0.0082 * * * \\
(-3.272)\end{array}$ & $\begin{array}{c}-0.0073 * * * \\
(-3.131)\end{array}$ & $\begin{array}{c}-0.0061^{* *} \\
(-2.709)\end{array}$ \\
\hline Tax & $\begin{array}{c}0.0121 \\
(0.500)\end{array}$ & $\begin{array}{l}-0.0210 \\
(-0.685)\end{array}$ & $\begin{array}{l}-0.0221 \\
(-0.711)\end{array}$ \\
\hline Leverage & $\begin{array}{c}-0.0086^{*} \\
(-1.760)\end{array}$ & $\begin{array}{l}-0.0078 \\
(-1.660)\end{array}$ & $\begin{array}{l}-0.0040 \\
(-1.034)\end{array}$ \\
\hline Constant & $\begin{array}{c}0.1434 * * * \\
(5.365)\end{array}$ & $\begin{array}{c}0.1113 * * * \\
(6.097)\end{array}$ & $\begin{array}{c}0.1296^{* * * *} \\
(7.468)\end{array}$ \\
\hline Industry F.E. & No & Yes & Yes \\
\hline Province F.E. & No & No & Yes \\
\hline Observations & 2257 & 2257 & 2257 \\
\hline $\mathrm{R}^{2}$ & 0.027 & 0.057 & 0.080 \\
\hline
\end{tabular}


Table 5. Alternative Event Windows and Market Models

\begin{tabular}{|c|c|c|c|c|c|c|}
\hline \multirow[b]{3}{*}{ Dep $=$ CARs } & \multicolumn{3}{|c|}{ Alternative Event Windows } & \multicolumn{3}{|c|}{ Alternative Market Models } \\
\hline & $(2)$ & $(3)$ & $(4)$ & (4) & $(5)$ & $(6)$ \\
\hline & CAR $(-5,10)$ & $\operatorname{CAR}(-10,10)$ & CAR $(-10,20)$ & Three Factor & $\begin{array}{c}\text { Weighted } \\
\text { Benchmark }\end{array}$ & Hushen300 \\
\hline Luxury & $\begin{array}{c}-0.0274 * * * \\
(-3.090)\end{array}$ & $\begin{array}{c}-0.0248 * * * \\
(-3.298)\end{array}$ & $\begin{array}{c}-0.0379 * * \\
(-2.446)\end{array}$ & $\begin{array}{c}-0.0317 * * * \\
(-3.092)\end{array}$ & $\begin{array}{c}-0.0327 * * * \\
(-3.327)\end{array}$ & $\begin{array}{c}-0.0357 * * * \\
(-3.498)\end{array}$ \\
\hline $\mathrm{SOE}$ & $\begin{array}{c}-0.0055 * * * \\
(-5.921)\end{array}$ & $\begin{array}{c}-0.0153 * * \\
(-2.769)\end{array}$ & $\begin{array}{c}-0.0204 * * * \\
(-3.554)\end{array}$ & $\begin{array}{c}-0.0059^{*} \\
(-1.982)\end{array}$ & $\begin{array}{c}-0.0067 * * \\
(-2.301)\end{array}$ & $\begin{array}{c}-0.0068 * * \\
(-2.363)\end{array}$ \\
\hline Size & $\begin{array}{c}-0.0051 * * * \\
(-5.921)\end{array}$ & $\begin{array}{c}-0.0088 * * * \\
(-9.178)\end{array}$ & $\begin{array}{c}-0.0129 * * * \\
(-8.762)\end{array}$ & $\begin{array}{l}-0.0011 \\
(-1.439)\end{array}$ & $\begin{array}{c}-0.0036^{* * *} \\
(-4.798)\end{array}$ & $\begin{array}{c}-0.0040 * * * \\
(-4.852)\end{array}$ \\
\hline Connected & $\begin{array}{c}-0.0051 * * \\
(-2.815)\end{array}$ & $\begin{array}{c}-0.0059 * * \\
(-2.608)\end{array}$ & $\begin{array}{l}-0.0015 \\
(-0.434)\end{array}$ & $\begin{array}{c}-0.0057 * * \\
(-2.544)\end{array}$ & $\begin{array}{c}-0.0061 * * \\
(-2.667)\end{array}$ & $\begin{array}{l}-0.0062 \\
(-2.728)\end{array}$ \\
\hline $\operatorname{Tax}$ & $\begin{array}{l}-0.0601 \\
(-1.337)\end{array}$ & $\begin{array}{l}-0.0545 \\
(-0.748)\end{array}$ & $\begin{array}{l}-0.0596 \\
(-0.543)\end{array}$ & $\begin{array}{l}-0.0060 \\
(-0.184)\end{array}$ & $\begin{array}{l}-0.0199 \\
(-0.638)\end{array}$ & $\begin{array}{l}-0.0300 \\
(-0.946)\end{array}$ \\
\hline Leverage & $\begin{array}{l}-0.0043 \\
(-1.130)\end{array}$ & $\begin{array}{c}-0.0164 * * * \\
(-3.395)\end{array}$ & $\begin{array}{c}-0.0259 * * * \\
(-3.131)\end{array}$ & $\begin{array}{l}-0.0044 \\
(-1.244)\end{array}$ & $\begin{array}{l}-0.0036 \\
(-0.924)\end{array}$ & $\begin{array}{l}-0.0050 \\
(-1.278)\end{array}$ \\
\hline Constant & $\begin{array}{c}0.1562 * * * \\
(7.795)\end{array}$ & $\begin{array}{c}0.2198 * * * \\
(9.999)\end{array}$ & $\begin{array}{c}0.2942 * * * \\
(10.606)\end{array}$ & $\begin{array}{c}0.0764 * * * \\
(4.488) \\
\end{array}$ & $\begin{array}{c}0.1224 * * * \\
(7.149)\end{array}$ & $\begin{array}{c}0.1480 * * * \\
(8.121)\end{array}$ \\
\hline Industry F.E. & Yes & Yes & Yes & Yes & Yes & Yes \\
\hline Province F.E. & Yes & Yes & Yes & Yes & Yes & Yes \\
\hline Observations & 2,257 & 2,257 & 2,257 & 2,257 & 2,257 & 2,257 \\
\hline $\mathrm{R}^{2}$ & 0.057 & 0.096 & 0.111 & 0.065 & 0.078 & 0.082 \\
\hline
\end{tabular}

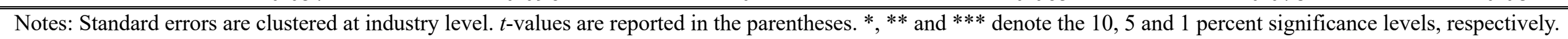


Table 6. Alternative measures of firm ownership, size, or political connections.

\begin{tabular}{|c|c|c|c|}
\hline \multirow[b]{2}{*}{ Dep $=$ CARs } & $(1)$ & $(2)$ & (3) \\
\hline & $\begin{array}{l}\text { Alternative } \\
\text { Ownership }\end{array}$ & Alternative Size & $\begin{array}{l}\text { Alternative } \\
\text { Connection }\end{array}$ \\
\hline Luxury & $\begin{array}{c}-0.0333 * * * \\
(-3.288)\end{array}$ & $\begin{array}{c}-0.0335 * * * \\
(-3.240)\end{array}$ & $\begin{array}{c}-0.0328 * * * \\
(-3.313)\end{array}$ \\
\hline SOE & & $\begin{array}{c}-0.0074 * * \\
(-2.366)\end{array}$ & $\begin{array}{c}-0.0066^{* *} \\
(-2.308)\end{array}$ \\
\hline SOE_2 & $\begin{array}{c}-0.0049 * * \\
(-2.203)\end{array}$ & & \\
\hline Size & $\begin{array}{c}-0.0039 * * * \\
(-4.851)\end{array}$ & & $\begin{array}{c}-0.0038 * * * \\
(-4.979)\end{array}$ \\
\hline Size_2 & & $\begin{array}{c}-0.0031 * * * \\
(-3.502)\end{array}$ & \\
\hline Connected & $\begin{array}{c}-0.0060 * * \\
(-2.382)\end{array}$ & $\begin{array}{c}-0.0065^{* *} \\
(-2.944)\end{array}$ & \\
\hline Connected_2 & & & $\begin{array}{c}-0.0049 * \\
(-1.774)\end{array}$ \\
\hline Tax & $\begin{array}{l}-0.0219 \\
(-0.703)\end{array}$ & $\begin{array}{l}-0.0360 \\
(-1.147)\end{array}$ & $\begin{array}{l}-0.0234 \\
(-0.758)\end{array}$ \\
\hline Leverage & $\begin{array}{l}-0.0044 \\
(-1.126)\end{array}$ & $\begin{array}{l}-0.0051 \\
(-1.606)\end{array}$ & $\begin{array}{l}-0.0042 \\
(-1.083)\end{array}$ \\
\hline Constant & $\begin{array}{c}0.1314 * * * \\
(7.624)\end{array}$ & $\begin{array}{c}0.0729 * * * \\
(8.8185)\end{array}$ & $\begin{array}{c}0.1298 * * * \\
(7.518)\end{array}$ \\
\hline Industry F.E. & Yes & Yes & Yes \\
\hline Province F.E. & Yes & Yes & Yes \\
\hline Observations & 2,257 & 2,257 & 2,257 \\
\hline $\mathrm{R}^{2}$ & 0.079 & 0.079 & 0.079 \\
\hline
\end{tabular}

Notes: Standard errors are clustered at industry level. $t$-values are reported in the parentheses. *, ** and ${ }^{* * *}$ denote the 10,5 and 1 percent significance levels, respectively. 
Table 7. The Role of Local Institutions

\begin{tabular}{|c|c|c|c|}
\hline Dep $=\operatorname{CAR}(5,5)$ & (1) & (2) & (3) \\
\hline SOE * Protection & $\begin{array}{l}0.0040^{*} \\
(1.980)\end{array}$ & & \\
\hline $\mathrm{SOE}^{*}$ FactorMarket & $\begin{array}{c}-0.0086^{* * *} \\
(-5.804)\end{array}$ & & \\
\hline SIZE * Protection & & $\begin{array}{c}0.0012 * * \\
(2.159)\end{array}$ & \\
\hline SIZE * FactorMarket & & $\begin{array}{c}-0.0026^{* * * *} \\
(-3.076)\end{array}$ & \\
\hline Connected $*$ Protection & & & $\begin{array}{l}0.0043 \\
(1.412)\end{array}$ \\
\hline Connected $*$ FactorMarket & & & $\begin{array}{c}-0.0067 * * \\
(-2.169)\end{array}$ \\
\hline Luxury & $\begin{array}{c}-0.0329 * * * \\
(-3.321)\end{array}$ & $\begin{array}{c}-0.0334 * * * \\
(-3.309)\end{array}$ & $\begin{array}{c}-0.0333 * * * \\
(-3.373)\end{array}$ \\
\hline SOE & $\begin{array}{l}0.0232^{*} \\
(1.661)\end{array}$ & $\begin{array}{c}-0.0069 * * \\
(-2.412)\end{array}$ & $\begin{array}{c}-0.0065^{*} \\
(-2.145)\end{array}$ \\
\hline Size & $\begin{array}{c}-0.0037 * * * \\
(-4.933)\end{array}$ & $\begin{array}{l}0.0056 \\
(1.461)\end{array}$ & $\begin{array}{c}-0.0038^{* * * *} \\
(-4.920)\end{array}$ \\
\hline Connected & $\begin{array}{c}-0.0059 * * \\
(-2.632)\end{array}$ & $\begin{array}{c}-0.0063 * * \\
(-2.854)\end{array}$ & $\begin{array}{l}0.0112 \\
(1.531)\end{array}$ \\
\hline Tax & $\begin{array}{l}-0.0170 \\
(-0.550)\end{array}$ & $\begin{array}{l}-0.0187 \\
(-0.585)\end{array}$ & $\begin{array}{l}-0.0227 \\
(-0.734)\end{array}$ \\
\hline Leverage & $\begin{array}{l}-0.0039 \\
(-1.053)\end{array}$ & $\begin{array}{l}-0.0033 \\
(-0.811)\end{array}$ & $\begin{array}{l}-0.0045 \\
(-1.116)\end{array}$ \\
\hline Constant & $\begin{array}{c}0.1230^{* * *} \\
(7.207)\end{array}$ & $\begin{array}{l}0.0413 \\
(1.053)\end{array}$ & $\begin{array}{c}0.1262^{* * *} \\
(7.236)\end{array}$ \\
\hline Industry F.E. & Yes & Yes & Yes \\
\hline Province F.E. & Yes & Yes & Yes \\
\hline Observations & 2,257 & 2,257 & 2,257 \\
\hline $\mathrm{R}^{2}$ & 0.083 & 0.082 & 0.081 \\
\hline
\end{tabular}

Notes: Standard errors are clustered at industry level. $t$-values are reported in the parentheses. *, ** and ${ }^{* * *}$ denote the 10,5 and 1 percent significance levels, respectively. 
Table 8. Long-term effects on entry of new firms at the industry level

\begin{tabular}{|c|c|c|c|c|c|c|c|}
\hline & \multirow{2}{*}{$\begin{array}{c}\text { Benchmark } \\
\text { (1) }\end{array}$} & \multicolumn{3}{|c|}{ Alternative Event Windows } & \multicolumn{3}{|c|}{ Alternative Market Models } \\
\hline & & $(2)$ & (3) & $(4)$ & $(5)$ & $(6)$ & $(7)$ \\
\hline & $\operatorname{CAR}(-5,5)$ & $\operatorname{CAR}(-5,10)$ & CAR $(-10,10)$ & CAR $(-10,20)$ & Three Factor & Weighted & Hushen 300 \\
\hline CAR*Post & $\begin{array}{c}4.8414 * * * \\
(5.577)\end{array}$ & $\begin{array}{c}3.0982 * * * \\
(5.194)\end{array}$ & $\begin{array}{c}2.7946^{* * *} \\
(5.703)\end{array}$ & $\begin{array}{c}1.9489 * * * \\
(5.735)\end{array}$ & $\begin{array}{c}4.1577 * * * \\
(4.608)\end{array}$ & $\begin{array}{l}4.8654 * * * \\
(5.594)\end{array}$ & $\begin{array}{c}4.6563 * * * \\
(5.345)\end{array}$ \\
\hline Industry FE & Yes & Yes & Yes & Yes & Yes & Yes & Yes \\
\hline Year FE & Yes & Yes & Yes & Yes & Yes & Yes & Yes \\
\hline Observations & 660 & 660 & 660 & 660 & 660 & 660 & 660 \\
\hline R-squared & 0.357 & 0.353 & 0.359 & 0.359 & 0.347 & 0.357 & 0.355 \\
\hline
\end{tabular}

Notes: Each regression includes a constant, industry fixed effects, and year fixed effects. parentheses. ${ }^{*},{ }^{* *}$ and ${ }^{* * *}$ denote the 10,5 and 1 percent significance levels, respectively. 
Table 9. Long-term effects on entry of new firms at the province-industry level

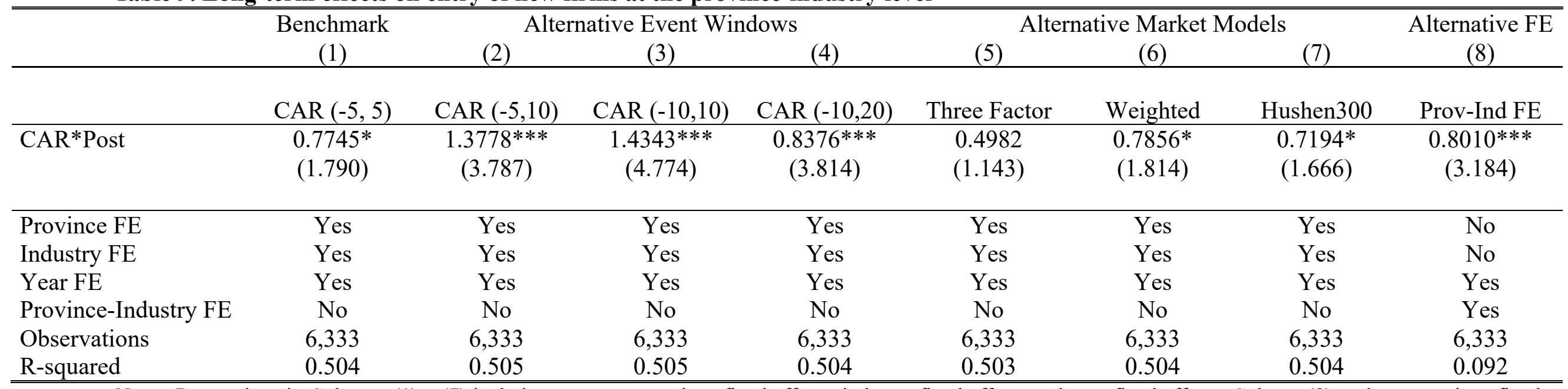

Notes: Regressions in Columns (1) - (7) include a constant, province fixed effects, industry fixed effects and year fixed effects. Column (8) replaces province fixed effects and industry fixed effects with the more stringent province-industry fixed effects. Standard errors are clustered at industry level. $t$-values are reported in the parentheses. ${ }^{*}, * *$ and $* * *$ denote the 10,5 and 1 percent significance levels, respectively. 
Table 10. Long-term effects on scales of on existing firms

\begin{tabular}{lccccccc}
\hline & Benchmark & \multicolumn{3}{c}{ Alternative Event Windows } & \multicolumn{3}{c}{ Alternative Market Models } \\
& $(1)$ & $(2)$ & $(3)$ & $(4)$ & $(5)$ & $(6)$ \\
\hline CAR*Post & CAR $(-5,5)$ & CAR $(-5,10)$ & CAR $(-10,10)$ & CAR $(-10,20)$ & Three Factor & Weighted & Hushen300 \\
& $0.2751^{* *}$ & $0.2025^{*}$ & $0.1708^{*}$ & $0.1330^{*}$ & $0.3001^{* *}$ & $0.2775^{* *}$ & $0.2613^{*}$ \\
& $(1.987)$ & $(1.690)$ & $(1.759)$ & $(1.765)$ & $(2.147)$ & $(2.001)$ & $(1.900)$ \\
& & & & & & & \\
Controls & Yes & Yes & Yes & Yes & Yes & Yes & Yes \\
Firm FE & Yes & Yes & Yes & Yes & Yes & Yes \\
Year FE & Yes & Yes & Yes & Yes & Yes & Yes \\
Observations & 15,523 & 15,523 & 15,523 & 15,523 & 15,523 & 15,523 & 15,523 \\
R-squared & 0.927 & 0.927 & 0.927 & 0.927 & 0.927 & 0.927 & 0.927 \\
\hline \hline
\end{tabular}

Notes: Each regression includes a constant, controls, firm fixed effects, and year fixed effects. Standard errors are clustered at industry level. $t$-values are reported in the parentheses. ${ }^{*},{ }^{*}$ and ${ }^{* * *}$ denote the 10,5 and 1 percent significance levels, respectively. 
Table 11. Evidence on the endogenous grits effect

Dependent Variable $=$ Overall marketization index

\begin{tabular}{lc}
\hline & $0.9074 * * *$ \\
Post & $(10.149)$ \\
& $5.5703^{* * *}$ \\
Constant & $(140.179)$ \\
& Yes \\
Province FE & 279 \\
\hline Observations & 31 \\
Number of Provinces & 0.529 \\
R-squared & \\
\hline
\end{tabular}

Notes: Standard errors are clustered at province level. $t$-values are reported in the parentheses. *, $* *$ and $* * *$ denote the 10,5 and 1 percent significance levels, respectively. 